\title{
Charter challenge of ban on direct-to-consumer advertising to be heard by Ontario court in mid-June
}

Published at www.cmaj.ca on Jun. 11.

Revised to include late-breaking information that the hearing has been postponed.

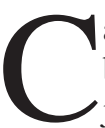

anWest Mediaworks Inc. has been granted an indefinite adjournment in a landmark Canadian Charter of Rights and Freedoms challenge case about direct-to-consumer prescription drug advertising that was scheduled to be heard in Ontario's Superior Court of Justice from Jun. 15-19.

Andrew Lokan, a lawyer for the financially troubled media giant, declined comment, but promised a public statement Jun. 12.

"CanWest is teetering on the verge of bankruptcy and has been for some time," said Steven Shrybman, a lawyer for a coalition of public interest groups that was granted intervener status in the case. He said the company should have pulled the plug on this "ill-conceived litigation" months ago instead of "at the 11th hour," and spared the federal government and the interveners the expense of preparing the court application.

In submissions made to the court earlier this year, the nub of the debate involved 2 very different takes on Canada's law than bans direct-to-consumer advertising of prescription drugs.

While Canwest will be free to revive the case at some future date, Shrybman says the coalition believes the case "has no merit and should be abandoned before any additional and needless litigation expenses are incurred."

Direct-to-consumer advertising is banned or strictly limited in all Western countries except New Zealand and the United States, where drug companies spend about US\$4-billion annually in a bid to boost sales.

The charter challenge was launched in December 2005. Since then, the affidavits of 18 expert witnesses have been filed with the court and, in an unusual

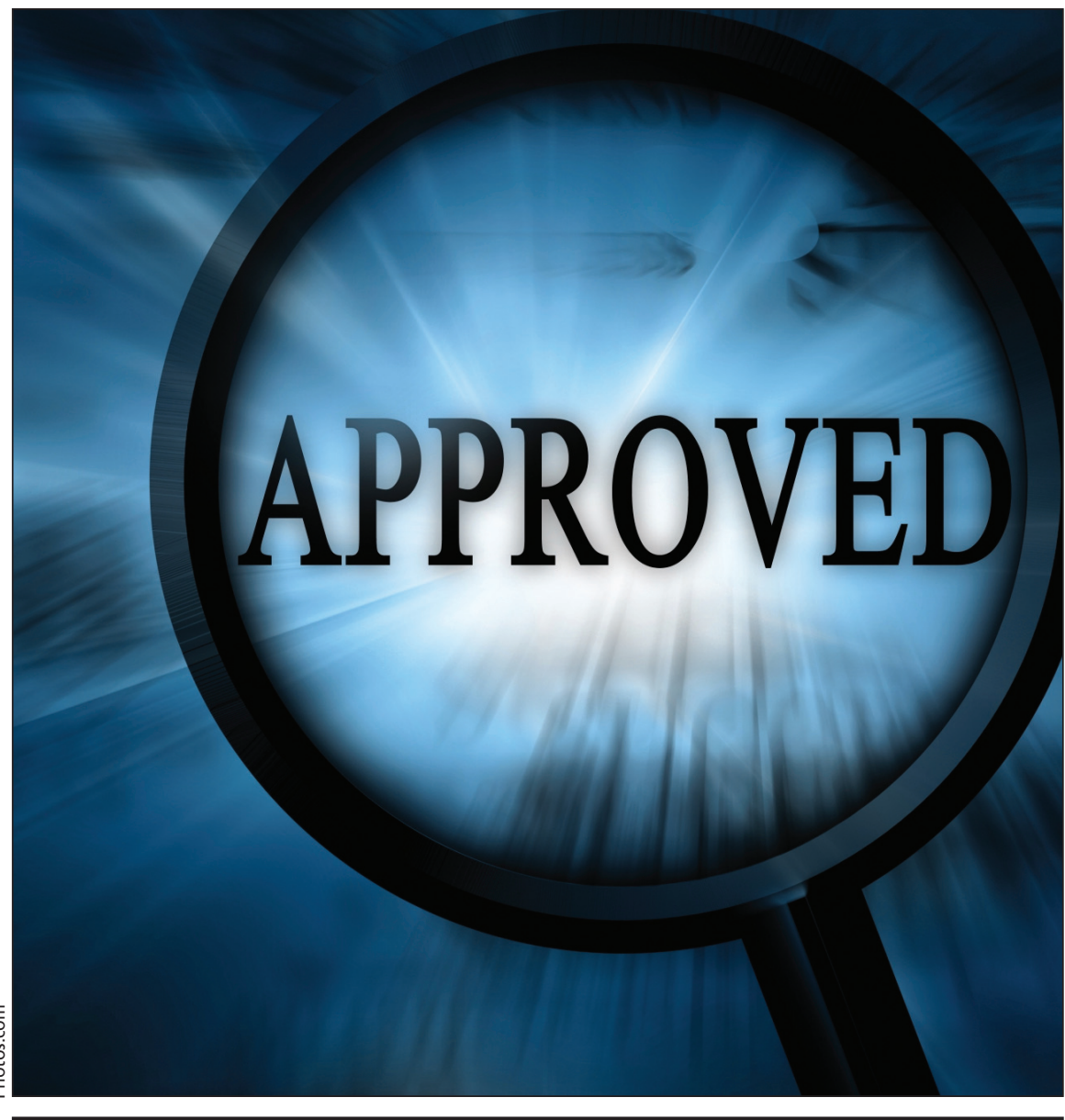

It's estimated that drug companies spend US\$4 billion annually promoting their products in the United States.

move, the court granted intervener status to a broad coalition of public interest groups, including the Canadian Federation of Nurses Unions, Women and Health Protection and the Canadian Health Coalition.

If the ban was lifted, the advertising of prescription drugs — and sales of such drugs - would significantly increase, the parties agree. But opinion differs on the impact of this change.

Media giant CanWest argues in its submission that the section of the Food and Drug Act that prohibits advertising to the public of a drug as a treatment or cure for certain diseases or disorders - so called "product specific" or "product claim" ads - contravenes a Charter provision that guarantees "freedom of thought, belief, opinion and expression, including freedom of the press and other media of communication.'

The ban also limits information that patients "have a right to receive" and is paternalistic, anachronistic and too broad, according to CanWest's brief.

But the Attorney General of Canada's submission states that the heart of the case is a balance between "the commercial interests" of CanWest and the societal interest of protecting Canadians, public health and 
the health care system from the harms of direct-to-consumer advertising of prescription drugs. The ban is justified by section 1 of the Charter, which guarantees rights and freedoms "subject only to such reasonable limits prescribed by law as can be demonstrably justified in a free and democratic society."

The Attorney General argues that CanWest doesn't provide evidence that its own "expressive rights" have been infringed by the ban and that it would be "more appropriate" for the pharmaceutical companies themselves to challenge the advertising ban.

For its part, the intervener coalition states that the ban restricts "commercial expression aimed at manipulating the public and patients about a complex and highly-specialized subject matter, namely prescription drugs, and as a result protects the Canadian public in an area in which they are particularly vulnerable."

Both the coalition and the federal government state that CanWest's only concern is that the ban stands in the way of it selling advertising. The media company would not be "accountable for any harm that branded or product specific promotional advertising would cause," the intervenor coalition contends.

CanWest argues that Canadian media "are penalized" because the federal government allows Canadians "to be bombarded" with prescription drug advertisements in cross-border United States media outlets.

As well, CanWest notes that the government does allow some prescription drug company advertisements to be broadcast by Canadian media. As a re- sult the system is "patchwork, irrational and antiquated," its submission states.

Customized Canadian drug company ads that dodge the letter of the law have proliferated over the past decade. They generally fall into 2 types: "Help seeking" ads mention a condition, but not the drug that treats it (reader/viewers are urged to contact their doctor/call a telephone number/visit a website); or "reminder ads" that mention a prescription drug but not its purpose.

These ads began appearing following a Health Canada policy interpretation of a regulation, dating back to the 1970s, intended to allow pharmacists to advertise drug prices.

For its part, the intervener coalition submission contends that Health Canada is lax in enforcement and permits Canadian drug company advertisements that "clearly extend well beyond" the limits permitted in regulations.

An example is the advertising campaign for Diane-35, a drug that is approved only for the treatment of severe and nonresponsive acne. A campaign of reminder television and print ads implied that the drug is a contraceptive and it was subsequently widely prescribed for that purpose. Meanwhile, Health Canada has issued safety warnings that, used as a contraceptive, the drug is 4 times more likely to cause potentially fatal drug clots than approved contraceptive drugs.

It also is "a matter of administrative policy and operation practice" that US drug company cross-border advertising is not restricted, even though it is not permitted in law. However, this lack of enforcement is irrelevant, the coalition argues. The "constitutional validity" of the Canadian ban on direct-to-consumer drug advertising "does not and cannot" be decided on how it is enforced or administered by the government.

Direct-to-consumer advertising has been the subject of ongoing review and consultation at Health Canada and "views remain polarized," the federal submission notes. In general, stronger prohibitions are favoured by "academia, patient groups, consumer groups most health professional and individuals," while drug companies and media supported more advertising.

The intervener coalition states that prescription drug advertising disproportionately affects women, who are more often the target of such ads and, in their care-giving roles in families, often make health care decisions for their children and other relatives. Women also live longer and have greater exposure to medicines for chronic diseases, the interveners state.

Yet the advertisements "fail to alert" women to the fact that clinical evidence of how a medication, such as statin drugs, will affect women is often limited. Meanwhile, most drugs selected for such advertising in the United States are newer, costlier drugs that offer no, or only marginal, benefit over existing drugs, and lack an extensive safety profile because they have not been fully tested on broad populations, the submission adds.

The Canadian Medical Association, Canadian Pharmacists Association and the Health Council of Canada are on record as opposing direct-to-consumer advertising of prescription drugs but are not members of the intervener coalition. - Ann Silversides, CMAJ

DOI:10.1503/cmaj.091050 